\title{
Drilling to the beds of the Greenland and Antarctic ice sheets: a review
}

\author{
Charles R. BENTLEY, Bruce R. KOCI \\ Ice Coring and Drilling Services, University of Wisconsin-Madison, 1225 West Dayton Street, Madison, WI 53706-1612, USA \\ E-mail: bentley@geology.wisc.edu
}

\begin{abstract}
We give a review of drilling to the beds of the Greenland and Antarctic ice sheets, with a history of just a century. We use a chronological rather than a geographical ordering to emphasize the way drilling has developed. The review is divided into two parts: core drilling and hole-only drilling for access to the beds or the deep interior of the ice sheets. This is an overview, not a comprehensive report on each project. While we have endeavoured to include all projects that fit our selection criteria, we have not provided all the technical details.
\end{abstract}

\section{INTRODUCTION}

In this paper we give an historical review of drilling to, or nearly to, the beds of the two polar ice sheets, with a history of just half a century. The focus on drilling that reached the beds arose from a paper contributed to a workshop on Subglacial Antarctic Lake Environments in Grenoble, France, in April 2006. We expanded our coverage to Greenland, because the drilling histories in Antarctica and Greenland are intimately intertwined. We set our boundary in the Arctic at the edge of the inland ice of Greenland, thus excluding drillings through all other glaciers and ice caps, including those around the periphery of Greenland.

We use a chronological rather than a geographical ordering because that is the way drilling has developed, and we want to emphasize this development. The review is divided into two parts. The first describes core drilling comprising 18 projects, 5 in Greenland and 13 in Antarctica. The second describes hole-only drilling for access to the beds or the deep interior of the ice sheet, comprising 12 projects, all but one of which, including the only one in Greenland, involved multiple holes. Except for the Cape Folger project, core-drilling projects are set out in order of completion (or near-completion), not starting dates, whereas hole-only projects are in order of starting dates, as many are ongoing and involve a sequence of holes.

This is an overview, not a comprehensive report on each project. While we do hope we have included all projects that fit our selection criteria, we do not claim to have provided all the technical details for each. Many additional details can be found using the References.

\section{HISTORY OF CORE DRILLING TO OR NEAR THE BED \\ Prologue}

This history begins with two drilling projects that did not reach to the beds, one at Site 2, Greenland, and one at Byrd Station, Antarctica. Both employed a Failing rotary welldrilling rig using cold compressed air as the drilling fluid; the ice chips were blown out of the hole by the air stream. This pioneering work in deep ice coring was performed by the US
Army Snow, Ice and Permafrost Research Establishment (USA-SIPRE). In Greenland, two holes were cored, the first reaching a depth of $296 \mathrm{~m}$ on 27 August 1956, and the second reaching a depth of $407 \mathrm{~m}$ in late boreal summer of 1957.

Meanwhile, in 1956, a duplicate of the Failing rig was shipped to Antarctica, arriving in December at Little America $\mathrm{V}$, from where it was shipped to Byrd Station in October 1957. Coring by SIPRE personnel commenced at Byrd Station on 16 December 1957, and terminated at a depth of $309 \mathrm{~m}$ on 26 January 1958. In February, the drill was returned to Little America (Patenaude and others, 1959; Lange, 1973).

\section{Little America, Antarctica, 1958-59}

The first drilling into the bed of an ice sheet was at Little America, near the front of the Ross Ice Shelf, Antarctica (Fig. 1), during the International Geophysical Year. Coring at Little America with the Failing rig was dry to $249 \mathrm{~m}$, then the hole was filled with diesel fuel for pressure balance; thereafter circulating fluid removed the chips. Drilling stopped on 5 December 1958 at $255 \mathrm{~m}$, 2 or $3 \mathrm{~m}$ above the base of the ice, when sea water entered the hole and rose to $188 \mathrm{~m}$. Core recovery was $98 \%$. The base of the ice was estimated at a depth of $257-258 \mathrm{~m}$ from seismic and

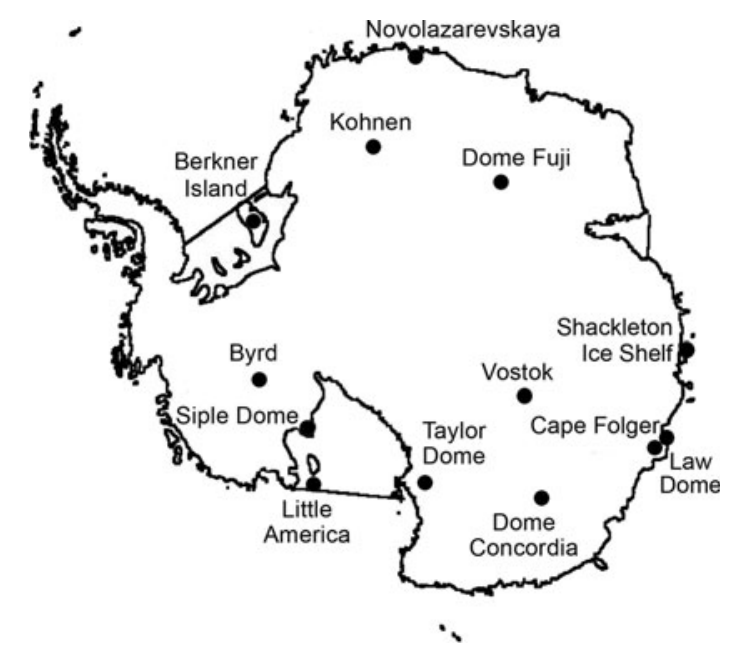

Fig. 1. Map of Antarctic deep core drilling sites. 


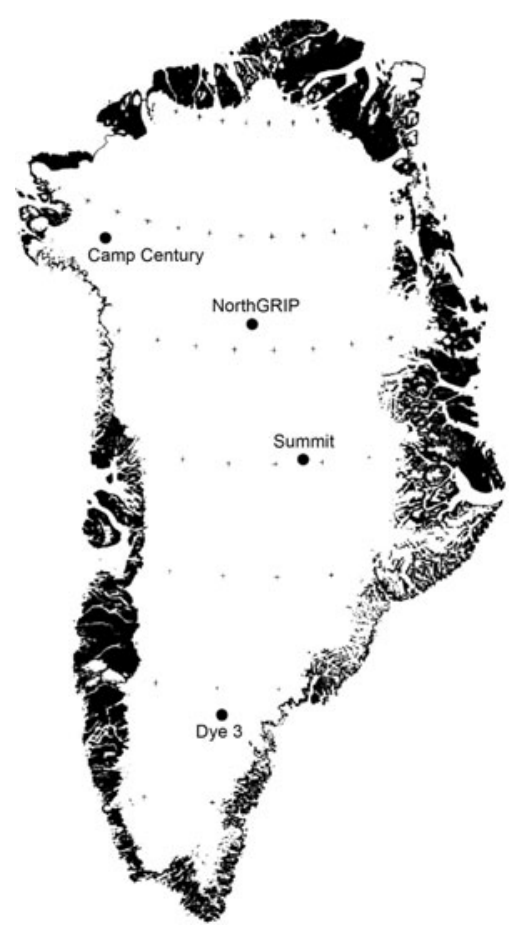

Fig. 2. Map of Greenland deep core drilling sites.

temperature measurements. The drilling was again done by SIPRE (Ragle and others, 1960; Gow, 1963; Lange, 1973).

\section{Camp Century, Greenland, 1961-66}

Drilling at Camp Century in northwest Greenland (Fig. 2) started in 1961. The drilling rig was installed on the floor of one of the covered-over, undersnow trenches in which the station was built. Using a thermal coring drill designed and built by the US Army Corps of Engineers Cold Regions Research and Engineering Laboratory (SIPRE had become CRREL in February 1961), holes of 186, 238 and $264 \mathrm{~m}$ depth were cored in 1961, 1962 and 1963, respectively. The third hole was extended to $535 \mathrm{~m}$ in 1964 after adding fluid. The drilling fluid was 'Diesel Fuel Arctic' (DFA) with trichloroethylene (TCE) as the densifier. In 1965 the hole was deepened to $1002 \mathrm{~m}$ using a modified commercial electromechanical drill (the 'Electrodrill'). The ice chips were removed by dissolving them in ethylene glycol, which was carried to the bottom of the hole in the drill with each run and brought back with the dissolved ice on each return trip. The bed at $1387.4 \mathrm{~m}$ was reached on 4 July 1966. Continuous core was recovered from all drilling. The bottom $17 \mathrm{~m}$ contained silt bands and small pebbles, and $3.55 \mathrm{~m}$ of frozen till was recovered from the bed. The basal temperature was $-13^{\circ} \mathrm{C}$ (Hansen and Langway, 1966; Ueda and Garfield, 1970).

\section{Byrd Station, Antarctica, 1966-68}

After reaching the bed at Camp Century, CRREL moved its drills immediately to Byrd Station in central West Antarctica. As at Camp Century, the rig was set $12 \mathrm{~m}$ below the surface in a station tunnel (Fig. 3). (This was the second Byrd Station, known as New Byrd, which was built in the early 1960s along the lines of Camp Century, i.e. in covered-over trenches.) The drill was set up, a pilot hole drilled with the CRREL Thermodrill, the casing set, and coring to $200 \mathrm{~m}$ was carried out in 1966/67. After the winter, on 1 November

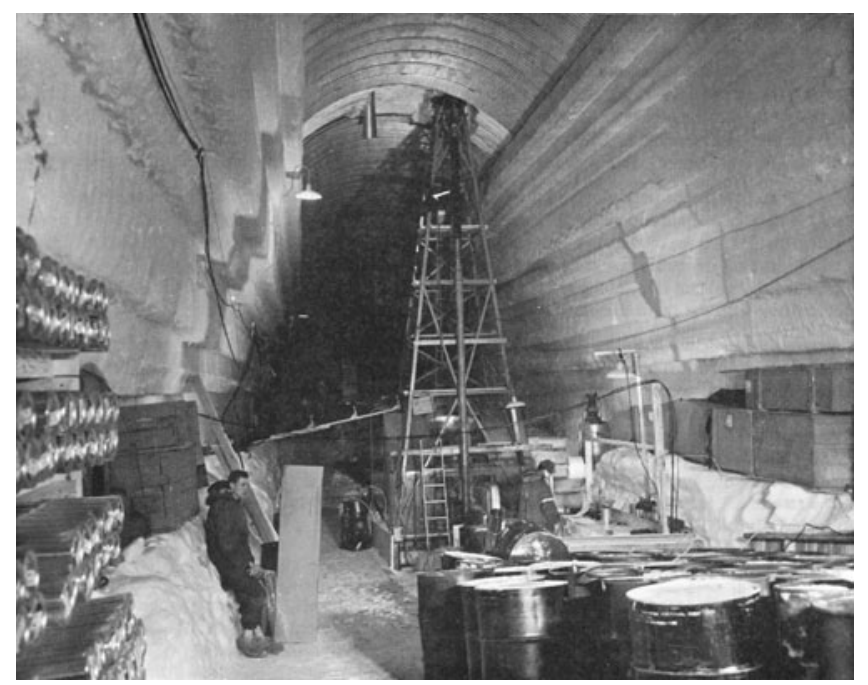

Fig. 3. CRREL electromechanical drill set-up in undersnow trench at Byrd Station, Antarctica.

1967, coring resumed with the Electrodrill. The drilling fluid was again DFA and TCE and ice chips were, as before, dissolved in ethylene glycol for removal. Drilling proceeded in two shifts, 24 hours a day, and reached the wet bed at $2164 \mathrm{~m}$ on 29 January 1968 . The upper $1250 \mathrm{~m}$ were drilled with a diamond bit (eight tungsten carbide inserts serving as matrices for surface-set diamonds); a steel bit worked better below $1250 \mathrm{~m}$, the approximate boundary between randomly oriented and highly vertically oriented $c$ axes in the ice. Englacial debris was encountered at $2160 \mathrm{~m}$, leading to a return to a diamond bit. A layer of water approximately $0.1 \mathrm{~mm}$ was found at the bed. The bed was penetrated to $1.3 \mathrm{~m}$, but no material was recovered. The drill was frozen in and lost following re-drilling into the bed in 1969 (Ueda and Garfield, 1969, 1970; Gow, 1970; Ueda, 2007).

\section{Cape Folger, Antarctica, 1969-83}

In 1969, the Australian National Antarctic Research Expeditions (ANARE) began an intermittent series of ice-core drillings near Cape Folger on Law Dome, East Antarctica, some of which penetrated nearly to the bed. That year, a modified CRREL thermal drill (Bird, 1976) was used to drill to a depth of $320 \mathrm{~m}$ at a location (SGA) about $7 \mathrm{~km}$ inland, where the surface elevation was about $300 \mathrm{~m}$ and the ice thickness about $350 \mathrm{~m}$. In 1974, at a spot $3 \mathrm{~km}$ farther upstream (SGP), two further thermal holes (separated by $100 \mathrm{~m}$ ) were drilled and cores collected. There, the surface elevation was $360 \mathrm{~m}$ and the ice thickness, determined by radar sounding, was $385 \mathrm{~m}$. More coring using the same modified CRREL thermal drill was done in the same area near Cape Folger during the 1981/82 austral summer (Morgan and others, 1984): hole BHC1, $301 \mathrm{~m}$ deep, was over a bedrock high point where the radar ice thickness was $303 \mathrm{~m}$, and BHC2, $344 \mathrm{~m}$ deep, was over a bedrock trough, with an ice thickness of $350 \mathrm{~m}$. These were all open holes, and rapid closure rates, particularly in the warm ice below about $250 \mathrm{~m}$, at times were a threat to trap the drill. All but the SGA hole were filled with fluid after the drilling was completed to keep them open for further measurements. These cores and boreholes have been used primarily for studies of crystal fabrics and ice dynamics (Russell-Head and Budd, 1979); Thwaites and others, 1984). 


\section{Novolazarevskaya, Antarctica, 1975/76}

In 1975/76, groups of the Soviet Antarctic Expeditions at Novolazarevskaya performed two ice-core drillings, 356 and $412 \mathrm{~m}$, respectively, through the nearby ice shelf, and a third one of $374 \mathrm{~m}$ through the local grounded ice. They used an electrothermal drill with alcohol as the drilling fluid, as a Soviet team with the Ross Ice Shelf Project did 3 years later (Morev and others, 1988; Horwath and others, 2006).

\section{Shackleton Ice Shelf, Antarctica, 1978/79}

The same Soviet group from the Arctic and Antarctic Research Institute in Leningrad and the Institute of Geography of the Academy of Sciences in Moscow, using the same kind of electrothermal coring drill with ethanol as the drilling fluid, reached the ocean through $202 \mathrm{~m}$ of ice on the Shackleton Ice Shelf, not far from Mirnyy station (Morev and others, 1988).

\section{Dye 3, Greenland (GISP), 1979-81}

The next deep core drilling, the Greenland Ice Sheet Project (GISP), was at the Dye 3 station in southern Greenland. It began in the summer of 1979, 12 years after the drilling at Byrd Station, following several years of shallow and intermediate drilling at 12 sites across Greenland. This was an international venture, involving groups from Denmark, Switzerland and the United States (Fig. 4). The drilling was done with the new Danish ISTUK electromechanical drill, much lighter than the massive CRREL drill used at Camp Century and Byrd Station, and introduced the tipping drill into deep ice-sheet coring. The tilting action reduced the height of the tower by 5 or $6 \mathrm{~m}$, but then required a slot several meters deep cut down from the ice-sheet surface to accommodate the lower part of the drill. The drilling fluid was kerosene (Jet A1) and perchloroethylene (PCE). Only steel cutters were used, in contrast to the grinding-type bits used by CRREL for the earlier drilling. Drilling reached $225 \mathrm{~m}$ in 1979, $901 \mathrm{~m}$ in 1980, and the bed at $2037 \mathrm{~m}$ in 1981. Silty ice was found at a depth of $2013 \mathrm{~m}$. The drill was stuck in 1981 but recovered in good condition in 1982 (Gundestrup and others, 1984; Gundestrup and Johnsen, 1985; Langway and others, 1985b).

\section{Summit, Greenland (GRIP), 1990-92}

Nearly another decade passed as the European GRIP (Greenland Icecore Project) and US GISP2 projects, separate but coordinated efforts $30 \mathrm{~km}$ apart, were planned for the Greenland summit. For the first time the site was chosen for scientific rather than logistic reasons. GRIP drilling with an improved ISTUK drill began in June, 1990 and ended in August at a depth of $770 \mathrm{~m}$. This was the first project to use the now-common combination of a low-aromatic solvent (Exxsol D60) with a fluorocarbon densifier (CFC-113), although a fluorocarbon densifier (CFC-11) was used with jet fuel (TS-1) by the Russians at Vostok as early as 1980. The drill was set in a trench $5 \mathrm{~m}$ wide and $5 \mathrm{~m}$ deep, into the floor of which was cut a $5 \mathrm{~m}$ deep slot for the drill to tilt into. Drilling continued to $2321 \mathrm{~m}$ in 1991 and reached the bed at $3029 \mathrm{~m}$ in July 1992, the first ice drilling to over $3 \mathrm{~km}$. The lowest $6.3 \mathrm{~m}$ were silty. There was no attempt to core the bed. The temperature at the bed was $-8.5^{\circ} \mathrm{C}$ (Johnsen and others, 1994, 1995).

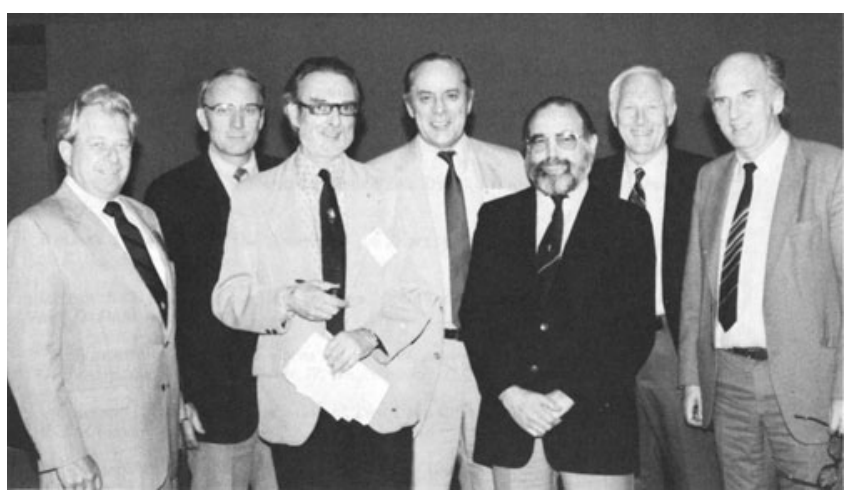

Fig. 4. The main players in organizing the GISP project at Dye 3. From the left: Duwayne Anderson, US National Science Foundation/Division of Polar Programs (NSF/DPP); Robert Rutford, NSF/ DPP; Willi Dansgaard, University of Copenhagen, Denmark; Chester Langway, State University of New York at Buffalo, USA; Richard Cameron, NSF/DPP; James Zumberge, US National Science Board; Hans Oeschger, University of Bern, Switzerland. From Langway, and others (1985a).

\section{Summit, Greenland (GISP2), 1989-93}

The GISP2 project employed the new US Polar Ice Coring Office (PICO) $132 \mathrm{~mm}$ (5.2 in) electromechanical drill that took cores up to $6 \mathrm{~m}$ long. For the first time, $n$-butyl acetate was used as the drilling fluid. A centrifuge system recovered the drilling fluid from the ice chips because of the high cost of the $n$-butyl acetate. The $31 \mathrm{~m}$ drill tower needed to accommodate the $27.5 \mathrm{~m}$ drill sonde remained vertical from the surface; full and empty core barrels were exchanged on the drill through a carousel arrangement. On 1 July 1993, after five seasons of drilling, the drill penetrated several meters of silty ice to reach the bed at $3053.4 \mathrm{~m}$ depth, $24 \mathrm{~m}$ deeper than GRIP, thus allowing the project to take over the claim of the deepest coring ever. In the silty ice the hardenedsteel cutters lasted only half as long as usual. Carbide-tipped cutters were an improvement, but only a few were available. A core $1.5 \mathrm{~m}$ in length and $50 \mathrm{~mm}$ in diameter was taken from the bed using a standard rock-coring diamond bit. The basal temperature was $-9^{\circ} \mathrm{C}$ (Mayewski and others, 1994; Stanford, 1994; Wumkes, 1994).

\section{Law Dome, Antarctica, 1987-93}

After a 20 year hiatus, deep core drilling finally returned to Antarctica at Law Dome, a local ice dome on the Budd Coast of Wilkes Land. Fieldwork by ANARE started in 1988 with thermal core drilling to $96 \mathrm{~m}$ and casing to $84 \mathrm{~m}$. Electromechanical drilling with an ISTUK-type drill reached $553 \mathrm{~m}$ in 1991/92 and $1200 \mathrm{~m}$ in February 1993. The drilling fluid was kerosene (Jet A1) and PCE. Silty ice was encountered at $1196 \mathrm{~m}$; drilling was terminated by an encounter with a rock fragment at $1200 \mathrm{~m}$. Total ice thickness, as determined by radio-echo sounding, is $\sim 1220 \pm 20 \mathrm{~m}$; ANARE glaciologists believe that the basal silty layer is probably no more than $20 \mathrm{~m}$ thick. The basal temperature was $-7^{\circ} \mathrm{C}$ (Morgan and others, 1994, 1997).

\section{Taylor Dome, Antarctica, 1993/94}

At Taylor Dome, a local ice dome just inland of the McMurdo Dry Valleys, a $554 \mathrm{~m}$ core into the bed was recovered in 1993/94 using the PICO $132 \mathrm{~mm}$ drill in an $n$-butyl-acetate-filled hole. Basal sediment $(60 \mathrm{~mm})$ and 
rock debris were also recovered. Actual drilling took 17 days, working around the clock. The basal temperature was $-26^{\circ} \mathrm{C}$ (Grootes and others, 1994).

\section{Siple Dome, Antarctica, 1996-99}

The $132 \mathrm{~mm}$ PICO drill was used again at Siple Dome, starting in 1996. Siple Dome is another local dome, in this case between ice streams bordering the eastern edge of the Ross Ice Shelf. Unfortunately, the drill was not in as good condition as on previous projects, making progress slow. The drilling fluid again was $n$-butyl acetate. Depths attained were $154 \mathrm{~m}$ in 1996/97, $351 \mathrm{~m}$ in 1997/98, and the bed at $1004 \mathrm{~m}$ in 1998/99. The temperature at the bed (where the pressure-melting point is $-0.8^{\circ} \mathrm{C}$ ) was $-2.54^{\circ} \mathrm{C}$. No problems were encountered with drilling in the warm ice, likely because of the large pumping rate used by this drill. No effort was made to drill into the bed (Engelhardt, 2004a, b; personal communication from K. Taylor, 2006). This drill has been retired and replaced in the US program by a new 'Deep Ice Sheet Coring' (DISC) drill (Shturmakov and others, 2007).

\section{NorthGRIP, Greenland, 1996-2003}

In Greenland, drilling on the multinational NorthGRIP project also started in 1996, reaching $350 \mathrm{~m}$. The drill was a new one designed and built as a cooperative European effort led by the University of Copenhagen, Denmark (Johnsen and others, 2007). The drilling fluid was Exxsol D60 and HCFC-141b. In 1997, drilling continued to $1371 \mathrm{~m}$, where the drill became stuck. Recovery attempts in 1998 were unsuccessful, so drilling was restarted in 1999, reaching $1750 \mathrm{~m}$. This was extended to $2930 \mathrm{~m}$ in 2000 , where the drill stuck again. This time it was freed, but there was no further drilling that season. Before drilling could recommence in 2001, 3 weeks were spent recovering the glycol that had been dumped down the hole during the previous season to retrieve the stuck drill. Drilling was then very slow (in warm ice), reaching only $3001 \mathrm{~m}$. The drill was stuck and freed four times during the season, using 2-3 kg of frozen glycol pellets each time. Finally, in July 2003 at $3085 \mathrm{~m}$ depth, subglacial water flooded into the hole. In 2004 the lowest $40 \mathrm{~m}$ was re-drilled to a several meters greater depth than in 2003, recovering $10 \mathrm{~m}$ of refrozen basal water. Pebbles, dirt and macrofossils were recovered from the bed (Dahl-Jensen and others, 2002; NorthGRIP members, 2004; Johnsen and others, 2007; personal communication from J. White, 2006).

\section{Dome C, Antarctica, 1996-2005}

Drilling started in 1996/97 at the DC1 site in central Wilkes Land, the current Concordia Station site $(56 \mathrm{~km}$ from the 1977-79 $900 \mathrm{~m}$ drilling site at the former Dome Charlie station), using the new EPICA (European Project for Ice Coring in Antarctica) drill, essentially the same as the NorthGRIP drill. The drilling fluid was Exxsol D30 and HCFC-141b. Coring continued throughout 1997-99, reaching $781 \mathrm{~m}$, where the drill became stuck. A new hole was begun at DC2, $10 \mathrm{~m}$ north from DC1, in 1999/2000. Depths attained in succeeding seasons were $1459 \mathrm{~m}$ in 2000/01, $2864 \mathrm{~m}$ in 2001/02 and $3200 \mathrm{~m}$ in 2002/03. Drilling was very slow in the warm basal ice. At $3120 \mathrm{~m}$ (temperature $-6.3^{\circ} \mathrm{C}$ ) the drilling production rate dropped abruptly from $35 \mathrm{~m} \mathrm{~d}^{-1}$ to almost zero as refrozen ice began to block the channels above the cutters. The solution was to inject an ethanol/water mixture into the bottom of the hole, at first by a separate injector device, then carried down in the chip chamber, a technique previously developed and used successfully at NorthGRIP. On 21 December 2004, drilling reached $3270 \mathrm{~m}, 5 \mathrm{~m}$ above the bed. The ice was expected to be melting at the bed, so drilling stopped at this depth to avoid contaminating the basal water. Small reddish-brown inclusions were found in the bottom $10 \mathrm{~m}$ of the core (Augustin and Antonelli, 2002; Augustin and others, 2007; Johnsen and others, 2007; personal communication from L. Augustin, 2006).

\section{Berkner Island, Antarctica, 2002-06}

Berkner Island is the ice rise that separates the Filchner and Ronne Ice Shelves. After setting casing there in 2002/03, core drilling by the British Antarctic Survey (BAS) and French colleagues began in 2003/04, reaching a depth of $526 \mathrm{~m}$. The drill was a slightly lengthened version of the Danish Hans Tausen drill (transportable in a Twin Otter aircraft); the drilling fluid was Exxsol D60 and HCFC-141b. The next season, drilling continued into the bed at $948 \mathrm{~m}$, attained on 12 January 2005. The last $2 \mathrm{~m}$ of core contained some grit particles. Attempts to drill into the bed yielded sand on the drill but no core. In 2005/06 a temperature of $-11^{\circ} \mathrm{C}$ was measured at the bed; additional attempts to core the bed with carbide-tipped steel cutters penetrated $0.5 \mathrm{~m}$ into the bed and produced several kilograms of fine sand but again no core (Johnsen and others, 2007; Mulvaney and Alemany, 2007; personal communications from R. Mulvaney, 2006, 2007).

\section{Dronning Maud Land, Antarctica, 2000-06}

Kohnen station, in northwestern Dronning Maud Land, was built and the hole casing set in 2000/01. Drilling below the casing, using the NorthGRIP drill, began in 2001/ 02, reaching $450 \mathrm{~m}$. Drilling fluid was Exxsol D40 and HCFC-141b. Continued drilling reached $1564 \mathrm{~m}$ and $2565 \mathrm{~m}$ at the end of 2002/03 and 2003/04, respectively. There was no drilling in the 2004/05 season. Drilling continued in 2005/06 to $2774 \mathrm{~m}$, attained on 17 January when water started coming into the hole. Attempts to drill deeper recovered only refrozen meltwater. Upon reducing the level of the drilling fluid, the water rose to $163 \mathrm{~m}$ above the base (Johnsen and others, 2007; personal communication from $\mathrm{H}$. Oerter, 2006; personal communication from F. Wilhelms, 2008).

\section{Vostok, Antarctica, 1970-98; 2005-07}

Deep coring at Vostok, in central East Antarctica, has a long history. It began in 1970 with completion of 507 m open hole $1 \mathrm{G}$ with the TELGA electrothermal drill. Coring continued in 1972, with the hole still open, to $952 \mathrm{~m}$. Attempts at deepening beyond that in 1973, still without fluid, failed because of hole closure. Another dry hole, started by deviation from $1 \mathrm{G}$ at $307 \mathrm{~m}$ depth, was drilled with TELGA to $905 \mathrm{~m}$ in 1974. Drilling efforts continued in succeeding years (1975-79) when a new electrothermal drill (TBZS, a successor to TELGA for drilling in fluid) was tested in a new hole 2G that was finally stopped at a depth of $\sim 500 \mathrm{~m}$. Drilling of the first deep fluid-filled hole 3G at Vostok started in 1980 with TELGA and TBZS-152M electrothermal drills; the latter was then changed (at $1501 \mathrm{~m}$ ) for the highfrequency electrothermal drill TBS-112 HF. The drilling of $3 \mathrm{G}$ was complicated by three major drilling accidents and two deviations and finally terminated in 1986, with the 


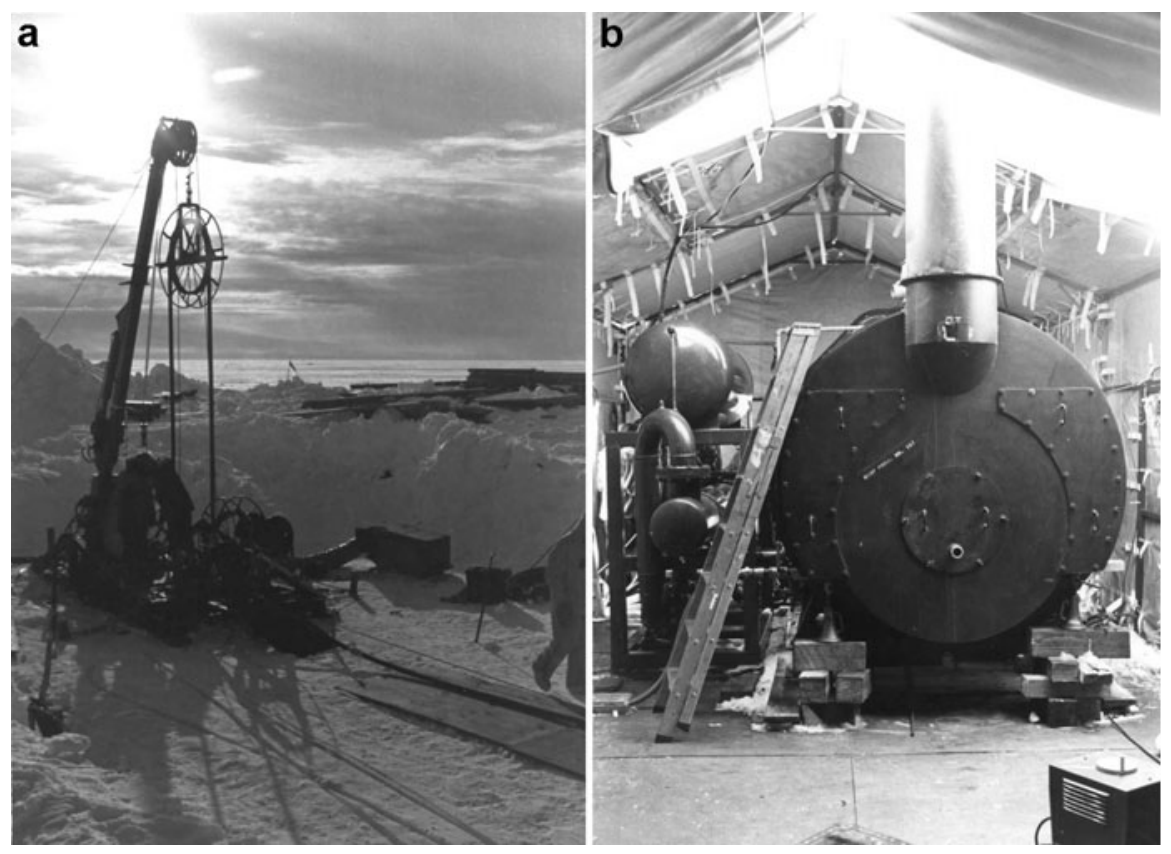

Fig. 5. The $2 \mathrm{MW}$ Browning hot-water drill used at Ross Ice Shelf Project station J9 to penetrate the ice shelf. (a) Scenic view of the drill surface unit in place. (b) The mammoth boiler for the drill; the $2.4 \mathrm{~m}(8 \mathrm{ft})$ stepladder gives the scale.

deepest branch-hole reaching a depth of $2002 \mathrm{~m}$. Meanwhile, new hole 4G was started in 1983 with TELGA and finished (after two accidents/deviations) to $2428 \mathrm{~m}$ with TBZS-152M. Drilling resumed in June 1989 with the KEMS112 electromechanical drill. At $2546 \mathrm{~m}$ the drill became stuck and was abandoned in November 1990. Also in 1990, hole 5G was started with TELGA and TPZS. In December 1991, when the hole depth reached $2502 \mathrm{~m}$, the drill became stuck and was eventually lost at a depth of $2259 \mathrm{~m}$. In 1992, deviation was made at depths of 2232-2246 $\mathrm{m}$ and branchhole 5G-1 was continued with the same TBZS drill. By 1993 the coring had reached $2755 \mathrm{~m}$. After Vostok was closed for a year, drilling resumed with a KEMS drill in 1995. From 1997 to 2007 , drilling was only during (short) summer seasons. A depth of $3623 \mathrm{~m}, \sim 130 \mathrm{~m}$ above Vostok Subglacial Lake, was reached in hole 5G-1 in February 1998. Ice accreted from the lake below was entered at a depth of $3540 \mathrm{~m}$.

After an 8 year hiatus to study whether and how to drill into Vostok Subglacial Lake, drilling resumed in 2005/06, reaching a depth of $3650 \mathrm{~m}$ on 22 January 2006. Difficulties with warm ice were encountered for the first time in the 2005/06 season. Drilling resumed in 2006/07 and continued into the austral winter. Progress has been very slow; as of 10 June 2007, the depth was $3661 \mathrm{~m}$. The drill was stuck at the bottom of the hole on 14 January 2007, but recovered on 7 February (Korotkevich and Kudryashov, 1976; Kudryashov and others, 1994, 2002; Vasiliev and Talalay, 2007; personal communication from V. Lipenkov, 2006; J Priscu, unpublished information).

\section{Dome Fuji, Antarctica, 1995-2006}

Drilling of the first hole at Dome Fuji, the western high dome of the East Antarctic ice sheet, started in August 1995 and reached $2504 \mathrm{~m}$ in December 1996. The drilling fluid was $n$-butyl acetate. The drill was irretrievably stuck at $2332 \mathrm{~m}$ by hole closure owing to an insufficient amount of fluid loading in the hole. Drilling started in a new hole in 2003/ 04 , reaching a depth of $362 \mathrm{~m}$, and continued to $1850 \mathrm{~m}$ in
2004/05. The depth of $3029 \mathrm{~m}$, several meters above the bed, was reached on 23 January 2006. Drilling was slow below $3000 \mathrm{~m}$ because of warm temperatures. Drilling continued in 2006/07 but was extremely slow, reaching only a depth of $3035 \mathrm{~m}$ below the surface. Refrozen meltwater and pebbles suggest that the bed is very near (Tanaka and others, 1994; Fujii and others, 2002; Takahashi and others, 2002; Motoyama, 2007).

\section{HISTORY OF CORELESS DRILLING TO OR NEAR THE BED}

\section{Ross Ice Shelf, Antarctica, 1976-79}

The first hole-only drilling through an ice shelf was part of the Ross Ice Shelf Project (RISP), which also included core drilling. RISP drilling, aiming to penetrate $420 \mathrm{~m}$ of ice at station J-9 on the southeastern Ross Ice Shelf, started in 1976/77 with a PICO wireline drill. This was a Longyear rig that drilled a hole $187 \mathrm{~mm}$ in diameter to retrieve a $60 \mathrm{~mm}$ core. The initial hole was left dry of drilling fluid to keep it clean; as a consequence, a greater than expected closure rate trapped the drill $90 \mathrm{~m}$ above the base $(420 \mathrm{~m})$ during a drill crew changeover. In 1977/78, attempts to melt out the wireline drill with hot water failed. A second, cobbledtogether wireline drill penetrated successfully to $170 \mathrm{~m}$ in a hole filled with a mixture of DFA and TCE; at that depth, time ran out at the end of the season. Concurrently, a Browning flame jet, producing $600 \mathrm{~kW}$ of thermal power, was used successfully to reach the ocean. Drilling rates for a $500 \mathrm{~mm}$ hole were $0.9 \mathrm{~m} \mathrm{~min}^{-1}$. A hole reached the water on 2 December 1977 after 9 hours drilling time, but it refroze. A second hole was completed on 14 December and kept open for 3 weeks by flame-reaming every 3-4 days. The hole diameter was kept at 300-460 mm (at isolated depths it was up to $750 \mathrm{~mm}$ ). A Browning $2 \mathrm{MW}$ hot-water drill system (Fig. 5) replaced the flame jet the following year (1978/79) and drilled several holes through the ice shelf that were up to $750 \mathrm{~mm}$ in diameter. Drilling time was $\sim 15$ hours. That 
same year a lightweight Russian electrothermal drill, using alcohol as antifreeze, provided continuous core to the iceshelf bottom and access to the ocean (Clough, 1977, 1978; Rand, 1977; Browning and Somerville, 1978; Clough and Hansen, 1979).

\section{Ekströmisen (Ekström Ice Shelf), Antarctica, 1985-95}

In January 1982, Ekströmisen was penetrated at Georg-vonNeumayer station by accident with a coring drill and the drill was lost. In 1985/86, a newly developed hot-water drill, to be used later that season on the central Ronne Ice Shelf, was tested by drilling two holes through $208 \mathrm{~m}$ of ice just south of the station. Drilling took 4 days. Three holes were drilled at (newly rebuilt and renamed) Neumayer station by AlfredWegener-Institut (AWI) personnel during the 1992/93 season, using a newly modified hot-water drill. The principal modification, to avoid the large hole inclination that occurred with drilling on the Ronne Ice Shelf the previous season, was to add winch electronics that prevented the nozzle from touching the bottom of the hole. The ice was $240 \mathrm{~m}$ thick. Holes were at least $350 \mathrm{~mm}$ across and no more than a few degrees from vertical. The actual drilling took 12 days. In 2005/06, four holes were drilled north of Neumayer station near the ice front (ice thickness 95-100 m) for installation of oceanographic instruments below the ice (Beck and others, 1987; Nixdorf and others, 1994a; personal communication from $\mathrm{H}$. Oerter, 2006).

\section{Ronne Ice Shelf, Antarctica - Germany, 1985-95}

After two unsuccessful attempts, the bottom was reached through the central Ronne Ice Shelf in February 1986. The ice was $465 \mathrm{~m}$ thick and the drilling took 12 hours. The drill was an updated version of a type used on Variegated Glacier in Alaska. The speed near the surface was $120 \mathrm{~m} \mathrm{~h}^{-1}$; the hole diameter was $70 \mathrm{~mm}$, which was reamed to $100 \mathrm{~mm}$. The ice was increasingly slushy below $430 \mathrm{~m}$ and the water level in the hole dropped to sea level. In 1989/90, the shelf was penetrated again five times with a $60 \mathrm{~mm}$ nozzle (one was enlarged with a $150 \mathrm{~mm}$ nozzle) near the ice front west of Filchner station, where the ice thickness was $239 \pm 2 \mathrm{~m}$. The holes were used for temperature measurements in the ice and water and to measure basal melt rates. One oceancurrent meter was deployed, but became stuck in the ice when pulled back for maintenance the same season. In 1991/92 the shelf was penetrated twice through $420 \mathrm{~m}$ (at station B15) with the AWI hot-water drill. The holes were strongly inclined: in each drilling it took $580 \mathrm{~m}$ of hose to reach the water. The steep slope meant that oceanographic instruments could not be lowered into the ocean. In 1994/95 two holes were bored: HWB2, near B15 (420 m of ice; drilling time 10 hours) and HWB3 (264 m; drilling time 5.5 hours) near the 1989/90 holes. At HWB2 there was a slush layer at the base. Instruments emplaced through the holes soon ceased transmitting data. Holes were reamed with a new $130 \mathrm{~mm}$ nozzle that circulated water inside a rounded tip and back up so there was no water jet; this was to eliminate the danger of the reamer going off into a new hole (Engelhardt and Determann, 1987a, b; Miller and Oerter, 1991; Nixdorf and others, 1994b, 1997; personal communication from $\mathrm{H}$. Oerter, 2006).

\section{Crary Ice Rise, Antarctica, 1987/88}

Two holes, $370 \mathrm{~m}$ and $480 \mathrm{~m}$, were drilled through Crary Ice Rise (near station 19 in the southeastern Ross Ice Shelf) in
1987/88, using a specially designed PICO hot-water drill that melted a $260 \mathrm{~mm}$ hole at an average rate of $0.5 \mathrm{~m} \mathrm{~min}^{-1}$. The drill was instrumented with inclinometers, thermistors and calipers. The bed was naturally frozen at both sites (temperatures -3.7 and $-5.7^{\circ} \mathrm{C}$, respectively), but was warmed up enough by the hot water to yield some mud and rocks; the drill penetrated $\sim 5 \mathrm{~m}$ of bottom sediments (Bindschadler and others, 1988, 1990; Koci and Bindschadler, 1989).

\section{Jakobshavn Isbræ, Greenland, 1988-89}

In 1988 and 1989, a joint group from Eidgenössische Technische Hochschule, Zürich, Switzerland and the University of Alaska Fairbanks, USA, drilled several boreholes at three sites in a line across Jakobshavn Isbræ, $\sim 50 \mathrm{~km}$ upstream from the glacier front. The holes at two flank sites reached the bed at 1540 and $1630 \mathrm{~m}$, respectively, whereas the deepest central hole, at $1560 \mathrm{~m}$, terminated still nearly $1 \mathrm{~km}$ above the deep bed of the glacier. The drill developed for this work was relatively lightweight $-1000 \mathrm{~kg}$ plus $30 \mathrm{~kg}$ $(100 \mathrm{~m})^{-1}$ for the hose - with the heaviest single piece weighing $180 \mathrm{~kg}$. The drill consisted of a $6 \mathrm{~m}$ long, $30 \mathrm{~mm}$ diameter drill stem with a nozzle diameter of 4.5-5.5 mm, and a $19 \mathrm{~mm}$ (inside diameter) hose. The water discharge rate was $60-80 \mathrm{~L} \mathrm{~min}^{-1}$; six to eight oil heating units heated the water to $80-90^{\circ} \mathrm{C}$. Drilling time to $1550 \mathrm{~m}$ was $\sim 20$ hours. A few cubic centimeters of bed material was retrieved from the bottom of one of the flank holes (Iken and others, 1989, 1993).

\section{Siple and Gould Coasts, Antarctica, 1988-2001}

Over a 12 year period (1988-2001) more than 100 holes were melted to the bed at 20 sites across the ice streams and interstream ridges of the Gould and Siple Coasts of West Antarctica, by teams from California Institute of Technology (Caltech), USA, using a hot-water drill of their own design and construction (the 'Kamb/Engelhardt' drill). Initially drilling was done with a nozzle flow rate of $40 \mathrm{Lmin}^{-1}$ at a temperature of $95^{\circ} \mathrm{C}$. In subsequent years this was increased to $80 \mathrm{~L} \mathrm{~min}^{-1}$. The objective was to investigate and understand mechanisms of ice-stream motion, so many measurements were made in the hole and especially at and in the bed. Where the bed was soft it was penetrated several meters and samples recovered. At some locations, video imagery was recorded within the borehole, and ice cores were taken using a hot-water ice corer. Hole depths ranged from 900 to $1200 \mathrm{~m}$ and were routinely completed in 16-26hours of drilling depending upon depth (Engelhardt, 2004a, b; personal communication from R. Bolsey, 2006).

\section{Ronne Ice Shelf, Antarctica - UK, 1990-2003}

BAS used a hot-water drill of their design and construction during 1990/91 and 1991/92 to penetrate ice 562 and $541 \mathrm{~m}$ thick, respectively, on the Ronne Ice Shelf. The drill had a nozzle flow rate of $80 \mathrm{~L} \mathrm{~min}^{-1}$. The holes were $200-250 \mathrm{~mm}$ in diameter and were drilled in 1-3 days. Repeated reaming kept the holes open for 5 days after drilling. Hole S1 (1990/ 91) encountered $15 \mathrm{~m}$ of slush at the base that was easily drilled but quickly refilled the hole. Repeated drops of a heavy streamlined weight were needed to force passage for the oceanographic instruments through the slush. No slush layer was found at S2 (1991/92). In 1995/96 S3 was drilled 
through $825 \mathrm{~m}$ of ice. In 1998/99 two sites were drilled (S4 and S5), through ice thicknesses of 941 and $763 \mathrm{~m}$, respectively. In 2002/03 four more holes were drilled (Fox $1-4)$ in the northern Ronne Ice Shelf. Thicknesses were 300$400 \mathrm{~m}$. There was weak basal melting at three holes and basal freezing at the fourth, near the northern edge of the shelf. At that site the drill entered slush in an apparent bottom crevasse some $70 \mathrm{~m}$ above the base of the ice. BAS drillers, according to K. Makinson (personal communication, 2006) 'found that at sites with a melting base, it is difficult to enlarge the hole near the ice water interface as heat from the nozzle is taken away by the underlying seawater. This narrowing can lead to a slot being cut by the instrument cable (also deflected by the ocean current) and the trapping of the instrument and occasionally its loss. Sites with slush/freezing bases do not suffer this problem' (see Makinson, 1994; Nicholls and others, 1997, 2001, 2004; personal communication from K. Nicholls and K. Makinson, 2006).

\section{South Pole, AMANDA, 1990-97}

Hot-water drilling for the englacial Antarctic Muon and Neutrino Detector Array (AMANDA) at Amundsen-Scott South Pole Station (ice thickness $2800 \mathrm{~m}$ ) began during the 1990/91 season. In the first season, an $800 \mathrm{~kW}$ hot-water system was able to drill a $0.5 \mathrm{~m}$ hole to $800 \mathrm{~m}$, so a single string of three photomultiplier tubes could be lowered into the ice to collect preliminary data. In 1992/93 a 1.2 MW drill was used to drill four holes to a depth of $1000 \mathrm{~m}$ to make the first array. An instrumented drill assured straightness (the holes had to be plumb within $1 \mathrm{~m}$ in $2500 \mathrm{~m}$ ) and measured hole diameter. A separate cable was used to support the hose and retrieve information from the drill. Drilling time was 70 hours and fuel consumption was $17000 \mathrm{~L}$ per hole. At $1000 \mathrm{~m}$ the bubbles in the ice had not formed the clathrates that would make the ice clear. Two years later (1994/95), a 1.8 MW system was used to drill to a depth of $2000 \mathrm{~m}$. Drilling time per hole was $\sim 80$ hours and fuel consumption $\sim 30000 \mathrm{~L}$. A maximum depth of $2500 \mathrm{~m}$ was reached in 1995/96 in 100 hours, consuming $38000 \mathrm{~L}$ of fuel. Power was increased to $2.2 \mathrm{MW}$ to accommodate longer deployment times as more detector modules were added to the strings. The final array consisted of 19 holes (author's information (B. Koci)).

\section{Amery Ice Shelf, Antarctica, 2000-06}

In 2000/01 a borehole 300-350 mm in diameter and $373 \mathrm{~m}$ deep was drilled through the Amery Ice Shelf at site AM02, the first of a series of holes as part of ANARE's Amery Ice Shelf Ocean Research (AMISOR) project. Drilling took 24 hours; alternate reaming and sampling then gave a hole nearly $500 \mathrm{~mm}$ across and kept it open for a week. No slush was reported - AM02 is believed to be a site of basal melting. One short ocean-bottom mud core was retrieved. In 2001/02 a $479 \mathrm{~m}$ deep borehole was melted at site AM01 (where coring to $315 \mathrm{~m}$ in 1968 yielded marine ice below $270 \mathrm{~m}$ ). A hydraulic connection to the ocean was made at a depth of $376 \mathrm{~m}$, still $100 \mathrm{~m}$ above the basal boundary. Several ice cores were taken with a Caltech-style hot-water corer. Highly porous 'honeycomb' ice was found at $390 \mathrm{~m}$. Attempts to core the ocean floor failed at this site. In 2003/04 a new hole was drilled at the AM01 site and an ocean-bottom core was this time successfully collected. In 2005/06, after increasing the flow rate of the drill from 45 to $80 \mathrm{~L} \mathrm{~min}^{-1}, \mathrm{AM} 03$ and AM04 were drilled, the former through $722 \mathrm{~m}$ with no marine ice and an apparently melting base and the latter through $603 \mathrm{~m}$ with $203 \mathrm{~m}$ of marine ice and a hydraulic connection to the ocean at around $525 \mathrm{~m}$. There was a minor basal 'necking' effect at AM03 owing to insufficient heat supply at this large depth, but passage of instruments in and out was not a problem. At AM04 the ice from $550 \mathrm{~m}$ to the base at $603 \mathrm{~m}$ was very irregular, so instruments were bumping against the walls as they were lowered and raised. Oceanographic instruments deployed below these holes are still yielding data (Craven and others, 2002, 2004, 2005, 2006); personal communication from M. Craven, 2006); personal communication from A. Elcheikh, 2006).

\section{McMurdo Ice Shelf, Antarctica, 2002/03}

In January 2003, two holes (70 and $140 \mathrm{~m}$ deep) were drilled through the ice as part of the ANDRILL project, to allow ocean bottom cores to be collected. The holes were $>0.5 \mathrm{~m}$ in diameter (Barrett and others, 2003; personal communication from H. Oerter, 2006).

\section{Rutford Ice Stream, Antarctica, 2004/05}

In 2004/05 BAS attempted to drill to the base of Rutford Ice Stream, through $2200 \mathrm{~m}$ of ice, with a beefed-up hot-water drill. The hose diameter was increased to 1.25 in $(32 \mathrm{~mm})$ (from $0.75 \mathrm{in}(19 \mathrm{~mm})$ ) and flow rate enhanced to $150 \mathrm{~L} \mathrm{~min}^{-1}$ (from $80 \mathrm{~L} \mathrm{~min}^{-1}$ ). Penetration was successful to $2000 \mathrm{~m}$, but a hose coupling (at the surface) then broke, a back-up system also failed and the entire $2000 \mathrm{~m}$ of hose was lost down the hole (personal communication from A. Smith, 2006; personal communication from K. Nicholls, 2006).

\section{South Pole, IceCube, 2004-06}

The IceCube drill design was based on the performance numbers obtained in the AMANDA drilling. Three hose reels were replaced by one gigantic winch containing $2700 \mathrm{~m}$ of $64 \mathrm{~mm}$ inside diameter hose to allow a complete hole to be drilled in a single continuous operation. Overall power was increased to $4.8 \mathrm{MW}$. To date, nine $650 \mathrm{~mm}$ diameter holes have been drilled to a depth of $2500 \mathrm{~m}$ and instrumented. Drilling time is $\sim 40$ hours (including reaming), permitting drilling of two holes per week. Maximum drilling speed is over $2 \mathrm{~m} \mathrm{~min}^{-1}$. Fuel consumption for the drilling is $\sim 20000 \mathrm{~L}$ per hole. Hole inclinations are about $0.1-0.2^{\circ}$ from vertical. Some 70 more holes will be drilled and instrumented over the next 5 years (author's information (B. Koci); personal communication from J. Cherwinka, 2006; personal communications from A. Elcheikh, 2006, 2007).

\section{ACKNOWLEDGEMENTS}

We thank those who provided much of the material included in this review, including M. Albert, L. Augustin, R. Bolsey, J. Cherwinka, J. Clough, M. Craven, A. Elcheikh, H. Engelhardt, S. Johnsen, K. Kuivinen, V. Lipenkov, K. Makinson, R. Mulvaney, K. Nicholls, H. Oerter, J. Rand, A. Smith, K. Taylor, M. Twickler, H. Ueda, J. White and F. Wilhelms. Helpful reviews were provided by R. Mulvaney and J. Schwander. Work for this paper was partly supported by the Office of Polar Programs, US National Science Foundation, under contract OPP-0003289. 


\section{REFERENCES}

Augustin, L. and A. Antonelli. 2002. The EPICA deep drilling program. Mem. Natl. Inst. Polar Res., 56, Special Issue, 226-244.

Augustin, L., S. Panichi, and F. Frascati. 2007. EPICA Dome C2 drilling operations: performances, difficulties, results. Ann. Glaciol., 47, 68-72.

Barrett, P. and 8 others. 2003. Recent history of the NW corner of the Ross Ice Shelf, Antarctica, from sediment cores. [Abstr. PP32D-08.] Eos, 84(46), Fall Meet. Suppl.

Beck, N., D. Wagenbach and O. Reinwarth. 1987. Nivologische und Spurenstoffglaziologische Arbeiten auf der Filchner II-Traverse und dem Ekström Schelfeis. Ber. Polarforsch., 33, 124-126.

Bindschadler, R.A., B. Koci and A. Iken. 1988. Drilling on Crary Ice Rise, Antarctica. Antarct. J. US, 23(5), 60-62.

Bindschadler, R.A., E.P. Roberts and A. Iken. 1990. Age of Crary Ice Rise, Antarctica, determined from temperature-depth profiles. Ann. Glaciol., 14, 13-16.

Bird, I.G, 1976. Thermal ice drilling: Australian developments and experiences. In Splettstoesser, J.F., ed. Ice-core drilling. Lincoln, NE, University of Nebraska Press, 1-18.

Browning, J.A. and D.A. Somerville. 1978. Access hole drilling through the Ross Ice Shelf. Antarct. J. US, 13(4), 55.

Clough, J.W. 1977. Ross Ice Shelf Project, 1976-1977. Antarct. J. US, 12(4), 142

Clough, J.W. 1978. Ross Ice Shelf Project 1977-78. Antarct. J. US, 13(5), 54.

Clough, J.W. and B.L. Hansen. 1979. The Ross Ice Shelf project. Science, 203(4379), 433-434.

Craven, M., A. Elcheikh, R. Brand and N. Jones. 2002. Hot water drilling on the Amery Ice Shelf - the AMISOR project. Mem., Natl. Inst. Polar Res. 56 Special Issue , 217-225.

Craven, M. and 6 others. 2004. Initial borehole results from the Amery Ice Shelf hot-water drilling project. Ann. Glaciol., 39, 531-539.

Craven, M. and 7 others. 2005. Borehole imagery of meteoric and marine ice layers in the Amery Ice Shelf, East Antarctica. J. Glaciol., 51(172), 75-84.

Craven, M., A. Elcheikh, R. Brand and I. Allison. 2006. Hot water drilling on the Amery Ice Shelf, East Antarctica. In Smedsrud, L.H., ed. Forum for Research into Ice Shelf Processes Report No. 14 (2006). Bergen, Bjerknes Centre for Climate Research. (Report Series R27.)

Dahl-Jensen, D. and 8 others. 2002. The NorthGRIP deep drilling programme. Ann. Glaciol., 35, 1-4.

Engelhardt, H. 2004a. Ice temperature and high geothermal flux at Siple Dome, West Antarctica, from borehole measurements. J. Glaciol., 50(169), 251-256.

Engelhardt, H. 2004b. Thermal regime and dynamics of the West Antarctic ice sheet. Ann. Glaciol., 39, 85-92.

Engelhardt, H. and J. Determann. 1987a. Borehole evidence for a thick layer of basal ice in the central Ronne Ice Shelf. Nature, 327(6120), 318-319.

Engelhardt, H. and J. Determann. 1987b. Heisswasserbohrungen und geophysikalische Untersuchungen auf dem Filchner und Ekström Schelfeis. Ber. Polarforsch. 33, 126-130.

Fujii, Y. and 25 others. 2002. Deep ice core drilling to $2503 \mathrm{~m}$ depth at Dome Fuji, Antarctica. Mem. Natl. Inst. Polar Res., $\mathbf{5 6}$ Special Issue, 103-116.

Gow, A.J. 1963. The inner structure of the Ross Ice Shelf at Little America V, Antarctica, as revealed by deep core drilling. IASH Publ. 61 (General Assembly of Berkeley 1963 - Snow and Ice), 272-284.

Gow, A.J. 1970. Preliminary results of studies of ice cores from the $2164 \mathrm{~m}$ deep drill hole, Byrd Station, Antarctica. IAHS Publ. 86 (Symposium at Hanover, New Hampshire 1968 - Antarctic Glaciological Exploration (ISAGE)), 78-90.

Grootes, P.M., E.J. Steig and M. Stuiver. 1994. Taylor Ice Dome study 1993-1994: an ice core to bedrock. Antarct. J. US, 29(5), 79-81.
Gundestrup, N.S. and S.J. Johnsen. 1985. A battery powered, instrumented deep ice core drill for liquid filled holes. In Greenland ice core: geophysics, geochemistry, and the environment. Washington, DC, American Geophysical Union, 19-22. (Geophysical Monograph 33.)

Gundestrup, N.S., S.J. Johnsen and N. Reeh. 1984. ISTUK: a deep ice core drill system. CRREL Spec. Rep. 84-34, 7-19.

Hansen, B.L. and C.C. Langway, Jr. 1966. Deep core drilling in ice and core analysis at Camp Century, Greenland, 1961-1966. Antarct. J. US, 1(5), 207-208.

Horwath, M. and 7 others. 2006. Nivlisen, an Antarctic ice shelf in Dronning Maud Land: geodetic-glaciological results from a combined analysis of ice thickness, ice surface height and iceflow observations. J. Glaciol., 52(176), 17-30.

Iken, A., K. Echelmeyer and W.D. Harrison. 1989. A light-weight hot water drill for large depth: experiences with drilling on Jakobshavns glacier, Greenland. In Rado, C. and D. Beaudoing, eds. Ice core drilling. Proceedings of the Third International Workshop on Ice Drilling Technology, Grenoble France, 10-14 October 1988. Grenoble, Centre National de la Recherche Scientifique. Laboratoire de Glaciologie et Géophysique de I'Environnement, 123-136.

Iken, A., K. Echelmeyer, W.D. Harrison and M. Funk. 1993. Mechanisms of fast flow in Jakobshavns Isbræ, West Greenland: Part I. Measurements of temperature and water level in deep boreholes. J. Glaciol., 39(131), 15-25.

Johnsen, S.J., N.S. Gundestrup, S.B. Hansen, J. Schwander and H. Rufli. 1994. The new improved version of the ISTUK ice core drill. Mem. Natl. Inst. Polar Res., 49 Special Issue, 9-23.

Johnsen, S.J., D. Dahl-Jensen, W. Dansgaard and N.S. Gundestrup. 1995. Greenland paleotemperatures derived from GRIP borehole temperature and ice core isotope profiles. Tellus, $47 \mathrm{~B}(5)$ 624-629.

Johnsen, S.J. and 16 others. 2007. The Hans Tausen drill; design, performance, further developments and some lessons learned. Ann. Glaciol., 47, 89-98.

Koci, B. and R. Bindschadler. 1989. Hot-water drilling on Crary Ice Rise, Antarctica. Ann. Glaciol., 12, 214.

Korotkevich, Y. and B.B. Kudryashov. 1976. Ice sheet drilling by Soviet Antarctic Expeditions. In Splettstoesser, J.F., ed. Ice-core drilling. Lincoln NE, University of Nebraska Press, 63-70.

Kudryashov, B.B., N.I. Vasiliev and P.G. Talalay. 1994. KEMS-112 electromechanical ice core drill. Mem. Natl. Inst. Polar Res. 49 Special Issue, 138-152.

Kudryashov, B.B. and 9 others. 2002. Deep ice coring at Vostok Station (East Antarctica) by an electromechanical drill. Mem. Natl. Inst. Polar Res. 56 Special Issue, 91-102.

Lange, G.R. 1973. Deep rotary core drilling in ice. CRREL Tech. Rep. 94.

Langway, C.C., Jr, H. Oeschger and W. Dansgaard. 1985a. Greenland ice core: geophysics, geochemistry, and the environment. Washington DC, American Geophysical Union. (Geophysical Monograph 33.)

Langway, C.C., Jr., H. Oeschger and W. Dansgaard. 1985b. The Greenland ice sheet program in perspective. In Greenland ice core: geophysics, geochemistry, and the environment. Washington, DC, American Geophysical Union, 1-8. (Geophysical Monograph 33.)

Makinson, K. 1994. BAS hot water drilling on Ronne Ice Shelf, Antarctica. Mem. Natl. Inst. Polar Res. 49 Special Issue, 192-202.

Mayewski, P.A. and 14 others. 1994. Record drilling depth struck in Greenland. Eos, 75(10), 133, 199, 124.

Miller, H. and H. Oerter, eds. 1991. Die Expedition ANTARKTISVIII mit FS Polarstern 1989/90, Bericht vom Fahrtabschnitt ANTVIII/5. Ber. Polarforsch 86, 67-69.

Morev, V.A., L.N. Manevskiy, V.M. Yakovlev and V.S. Zagorodnov. 1988. Drilling with ethanol-based antifreeze in Antarctica. In Rado, C. and D. Beaudoing, eds. Ice core drilling. Proceedings 
of the Third International Workshop on Ice Drilling Technology, Grenoble, France, 10-14 October 1988. Grenoble, Centre National de la Recherche Scientifique. Laboratoire de Glaciologie et Géophysique de l'Environnement, 110-113.

Morgan, V.I., A.P. McCray and E. Wehrle. 1984. Ice drilling at Cape Folger, antarctica. CRREL Spec. Rep. 84-34, 85-86.

Morgan, V., E. Wehrle, A. Fleming, M. Richardson, A. Elcheikh and R. Brand. 1994. Technical aspects of deep ice drilling on Law Dome. Mem. Natl. Inst. Polar Res. 49 Special Issue, 78-86.

Morgan, V.I., C.W. Wookey, J. Li, T.D. van Ommen, W. Skinner and M.F. Fitzpatrick. 1997. Site information and initial results from deep ice drilling on Law Dome, Antarctica. J. Glaciol., 43(143), 3-10.

Motoyama, H. 2007. The second deep ice coring project at Dome Fuji, Antarctica. Sci. Drilling, 5, 41-43.

Mulvaney, R., O. Alemany and P. Passenti. 2007. The Berkner Island ice-core drilling project. Ann. Glaciol., 47, 115-124.

Nicholls, K.W., K. Makinson and M.R. Johnson. 1997. New oceanographic data from beneath Ronne Ice Shelf, Antarctica. Geophys. Res. Lett., 24(2), 167-170.

Nicholls, K.W., S. Österhus, K. Makinson and M.R. Johnson. 2001. Oceanographic conditions south of Berkner Island, beneath Filchne-Ronne Ice Shelf, Antarctica. J. Geophys. Res., 106(C6), 11,481-11,492.

Nicholls, K.W., K. Makinson and S. Østerhus. 2004. Circulation and water masses beneath the northern Ronne Ice Shelf, Antarctica. J. Geophys. Res., 109(C12), C12017. (10.1029/ 2004JC002302.)

Nixdorf, U., H. Oerter and H. Miller. 1994a. First access to the ocean beneath Ekströmisen, Antarctica, by means of hot-water drilling. Ann. Glaciol., 20, 110-114.

Nixdorf, U., H. Mandler, C. Wege and A. Ziffer. 1994b. Heisswasserbohrung. Ber. Polarforsch. 152, 191-194.

Nixdorf, U., H. Mandler, C. Wege and A. Ziffer. 1997. SchelfeisOzean-Wechselwirkung. Ber. Polarforsch. 219, 69-88.

North Greenland Ice Core Project (NorthGRIP) members. 2004. High-resolution record of Northern Hemisphere climate extending into the last interglacial period. Nature, 431(7005), 147-151.
Patenaude, R.W., E.W. Marshall, and A. Gow. 1959. Deep core drilling in ice, Byrd Station, Antarctica. SIPRE Tech. Rep. 60.

Ragle, R.H., B.L. Hansen, A. Gow and R.W. Patenaude. 1960. Deep core drilling in the Ross Ice Shelf, Little America V, Antarctica. SIPRE Tech. Rep. 70.

Rand, J.H. 1977. Ross Ice Shelf drilling, October-December 1976. Antarct. J. US, 12(4), 150-152.

Russell-Head, D.S. and W.F. Budd. 1979. Ice-sheet flow proerties derived from bore-hole shear measurements combined with icecore studies. J. Glaciol., 24(90) 117-130.

Shturmakov, A.J., D.A. Lebar, W.P. Mason and C.R. Bentley. 2007. A new $122 \mathrm{~mm}$ electromechanical drill for deep ice-sheet coring (DISC): 1. Design concepts. Ann. Glaciol., 47, 28-34.

Stanford, K.L. 1994. Future technical developments for the Polar Ice Coring Office $13.2 \mathrm{~cm}$ ice coring drill. Mem. Natl. Inst. Polar Res. 49 Special Issue, 57-68.

Takahashi, A. and 13 others. 2002. Improvements to the JARE deep ice core drill ice. Mem. Natl. Inst. Polar Res. 56 Special Issue, 117-125.

Tanaka, Y. and 6 others. 1994. Development of a JARE deep ice core drill system. Mem. Natl. Inst. Polar Res. 49 Special Issue, 113-123.

Thwaites, R.J., C.J.L. Wilson and A.P. McCray. 1984. Relationship between borehole closure and crystal fabrics in an Antarctic ice core from Cape Folger. J. Glaciol., 30(105), 171-179.

Ueda, H.T. 2007. Byrd Station drilling 1966-69. Ann. Glaciol., 47, $24-27$.

Ueda, H.T. and D.E. Garfield. 1968. Drilling through the Greenland ice sheet. CRREL Spec. Rep. 126.

Ueda, H.T. and D.E. Garfield. 1969. Core drilling through the Antarctic ice sheet. CRREL Tech. Rep. 231.

Ueda, H.T. and D.E. Garfield. 1970. Deep core drilling at Byrd Station, Antarctica. IASH Publ. 86 (Symposium at Hanover 1968 - Antarctic Glaciological Exploration (ISAGE)), 56-62.

Vasiliev, N. and 8 others. 2007. Deep drilling at Vostok station, Antarctica: history and events. Ann. Glaciol., 47, 10-23.

Wumkes, M.A. 1994. Development of the US deep coring ice drill. Mem. Natl. Inst. Polar Res. 49 Special Issue, 41-51. 